\title{
In Situ Evaluation of Orthodontic Elastomeric Chains
}

\author{
Carolina BARATIERI \\ Cláudia Trindade MATTOS \\ Matheus ALVES JR \\ Thiago Chon Leon LAU \\ Lincoln Issamu NOJIMA \\ Margareth Maria Gomes de SOUZA \\ Monica Tirre ARAUJO \\ Matilde da Cunha Gonçalves NOJIMA
}

Department of Orthodontics, Dental School, UFRJ - Universidade Federal do Rio de Janeiro, Rio de Janeiro, RJ, Brazil

\begin{abstract}
The hypothesis tested in this study was that intraoral exposure of elastomeric chains alters their tensile strength. For such purpose, it was evaluated the in situ behavior of different elastomeric chains stretched for 3 weeks. Three kinds of elastomeric chains, Plastic chain (PC), Memory chain (MC) and Super slick chain (SSC), were randomly placed in 3 quadrants of 13 patient in a fixed distance of $16 \mathrm{~mm}$ and mean initial force of $180 \mathrm{~g}$. Tensile testing was performed in an universal testing machine at different intervals: initial, $1 \mathrm{~h}, 24 \mathrm{~h}, 1$ week, 2 weeks and 3 weeks. A two-way ANOVA test was performed to identify the influence of both material and time on the force decrease. A subsequent one-way ANOVA test with the Tukey's post hoc test was used to identify statistically significant intragroup and intergroup remaining force ( $\mathrm{g}$ and \%) differences at $5 \%$ significance level. The effect of both the material and the time factors were significant. All groups showed significant force decrease after the 1-h period (23\% for PC and $14 \%$ for MC and SSC). At the end of the 3-week period, the remaining force was 57\% (96 g), 67\% (129 g) and 71\% (125 g) for PC, MC and SSC, respectively. In conclusion, intraoral exposure of elastomeric chains altered their tensile strength. In general, the greater force decrease occurred within the first hour. The remaining force of the enhanced chains measured at each time interval was greater than the conventional one (PC). After 3 weeks, only the enhanced chains maintained the force applied over $100 \mathrm{~g}$.
\end{abstract}

Key Words: elastomeric chain, force-decay, Orthodontics, in situ.

\section{INTRODUCTION}

Elastomeric chains have been widely used in Orthodontics since the 1960s and its effects has been evaluated since then (1-5). They are used to deliver continuous light forces during sliding mechanics in diastema closure (6), rotational correction, and mainly during canine retraction after premolar extraction $(7,8)$. When stretched and exposed to the oral environment, the chains may absorb humidity and suffer a breakdown of internal bonds, which leads to permanent deformation (3). A rapid loss of force occurs due to stress relaxation, resulting in a gradual loss of effectiveness, which can be different for each kind of elastomeric chain (9-12).
Orthodontic elastomeric chains with enhanced properties that are claimed to provide greater efficacy during mechanics have been introduced lately. Better memory elastic properties were introduced in the earliest 1990s (Memory Chain; American Orthodontics, Sheboygan, WI, USA). The manufacturer claims the chain provides a lighter, yet longer lasting force. A different type of elastomeric chain was introduced in 2000 (Super Slick; TP Orthodontics Inc., La Porte, IN, USA) with metafasix technology. A water-insoluble, hydrogel-polymer coating, which, in contact with moisture, transforms the polyurethane-based elastomeric surface into a highly smooth surface, is claimed by the manufacturer to decrease friction. Despite the advertised 
benefits about this enhanced chains, very few specific studies have been conduced $(13,14)$.

Force degradation of elastomeric chains has been previously studied and discussed. The majority of studies have been conducted in vitro $(3,4,10-12,15-19)$ or in vivo $(3,8,9,18)$. In all studies, substantial decrease occurred after stretching. Various studies have shown significant amount of force degradation (13-75\%) within the first 24 $\mathrm{h}$ after elastomeric chain application $(9,11,17,20)$. This variation range depends on several situations, such as elastomeric chain composition and size, environment, evaluation period, evaluation method, pre-stretching as well as initial force applied. Some questions still remain concerning the range of initial force that must be applied to be effective and for how long the remaining force may be still considered clinically effective.

In vivo testing seems to be the ideal condition to analyze the behavior of elastomeric chains currently used under load. However, the great individual responses to orthodontic forces and the difficulties to standardize the distance or initial force during retraction increases substantially the sample size to find differences among elastomeric chain types. An in vitro evaluation allows a level of simplification of the system under study, so that the investigator can focus on a small number of components and exclude some variables. Despite the advantages of in vitro experiments, no artificial environment exactly duplicates the oral cavity. Therefore, an in situ evaluation combines the standardization of the in vitro testing with in vivo environment.

The hypothesis tested was that intraoral exposure of elastomeric chains alters their tensile strength. Thus, the aim of this study was to evaluate the in situ behavior of different elastomeric chains stretched for 3 weeks.

\section{MATERIAL AND METHODS}

This randomized in situ study was performed at

Table 1. Description of the elastomeric chains evaluated.

\begin{tabular}{ccc}
\hline $\begin{array}{c}\text { Commercial } \\
\text { name/group }\end{array}$ & $\begin{array}{c}\text { Chain } \\
\text { size }\end{array}$ & Manufacturer \\
\hline Plastic Chain & Closed & American Orthodontics, \\
(PC) & 5-unit & Sheboygan, WI, USA \\
Memory Chain & Short & American Orthodontics, \\
(MC) & 4-units & Sheboygan, WI, USA \\
Super Slick chain & Mini & TP Orthodontics, La Porte, \\
(SSC) & 5-units & IN, USA \\
\hline
\end{tabular}

the Department of Orthodontics of the Federal University of Rio de Janeiro, Brazil, after approval by the Ethics Committee of the Institute of Collective Health Studies (process \#0072.0.239.000-10) of the same University. The tested elastomeric chains are described in Table 1.

A sample size calculation suggested that 13 individuals should be sufficient to find tensile strength changes, with a significance level of 0.05 and a power of 0.95 . The patients ( 10 females and 3 males, mean age of 28.5 years) were selected based on the following inclusion criteria: fixed edgewise standard appliance in the finishing stage of the orthodontic treatment, with full $0.019 \times 0.025$-inch stainless steel archwires in both arches; adequate space to attach two crimpable hooks (in three quadrants) to the archwire in the interbracket space distanced exactly $16 \mathrm{~mm}$ from each other; good oral health; agreement to sign an informed consent form previously approved by the Ethics Committee.

In all patients, two crimpable hooks (Morelli Ortodontia, Sorocaba, SP, Brazil) were attached and soldered to the archwire in $3 \mathrm{hemi}$-arches with the fixed distance of $16 \mathrm{~mm}$ between them. One hook was placed distal to the canine and the other was placed mesial to the first molar (Fig. 1). This distance was previously established after measuring the distance between the middle of the buccal surfaces of the canine and the second premolar in 30 volunteers (mean distance of 16.24 $\mathrm{mm}$ ). Hence, it was considered to be the elastomeric chain extension needed in the first moment for canine retraction after extraction of first premolars.

Each elastomeric chain type was tested beforehand in different sizes and with a different number of units to standardize the initial force delivered by them. The sizes and the number of units chosen (Table 1) were the ones in which initial force close to $180 \mathrm{~g}$ was delivered when the chain was stretched in the stipulated distance, which

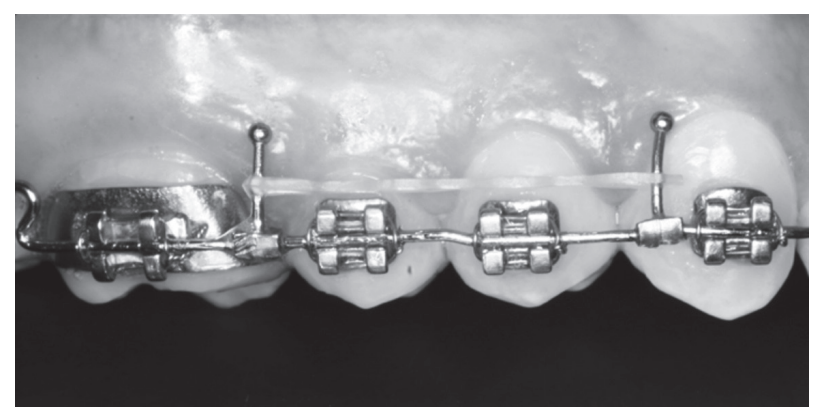

Figure 1. A stretched elastomeric chain inserted on hooks attached to the archwire. 
was considered to be ideal to simulate a canine retraction (21). The elastomeric chains were randomly placed in 3 quadrants of the selected patients and maintained in the oral cavity during 3 consecutive weeks. The hook conditions and the distance between them were checked during each appointment.

In the beginning of the study, all patients received a new toothbrush and a fluoride toothpaste. No especial diet was prescribed to the volunteers. Strict control of oral hygiene was maintained and checked at each clinical appointment.

Thirty-nine test quadrants provided data on 13 pieces of elastomeric chain of each type, which were tested in tensile strength at 6 time intervals: initial, 1 h, 24 h, 1 week, 2 weeks and 3 weeks. Tensile testing was performed in a universal testing machine (DL 10,000; EMIC, São José dos Pinhais, PR, Brazil). Attachments were adapted for the testing machine consisting of two L-shaped solid pieces of stainless steel where the elastomeric chain could be properly inserted. The distance between these two end points was confirmed to be $16 \mathrm{~mm}$ by a digital caliper (727-6/150; Starret Ind. e Com. Ltda., Itu, SP, Brazil). Each tested specimen was carefully removed from the oral cavity with a customized device used to hold and transfer it to the testing machine held at constant stretch. Once the specimen was positioned in the testing machine, the force generated on the end points was determined. Room temperature and humidity were standardized during the entire experimental period.

A blinded statistician performed the statistical analysis. Means and standard deviations for the remaining force in grams at the evaluated intervals and relative percentages of the initial force were calculated. As normality and homogeneity of variance criteria were fulfilled for all 3 groups of elastomeric chain types evaluated, parametric tests were used. A two-way ANOVA test was performed to identify the influence of both material and time on the force decrease. A subsequent one-way ANOVA test with Tukey's post hoc test was used to identify statistical significant intragroup and inter-group differences at 5\% significance level. All statistical analyses were performed using the SPSS software (version 17.0; SPSS, Chicago, IL, USA).

\section{RESULTS}

The two-way ANOVA test showed that the effect of both the material factor and of the time factor was significant $(p<0.001)$. The material factor accounted for $12.14 \%$ and the time factor accounted for $51.75 \%$ of total variation observed in the groups.

As the initial force was not exactly the same in all groups, the percentage of the force was calculated in each period. This allowed a better comparison of the remaining force among groups.

The mean values and standard deviations (SD) of the tensile force in grams ( $\mathrm{g}$ ) and percentage (\%) of the groups (PC, MC and SSC) at each time interval are presented in Table 2. The mean initial force applied decreased in all 3 groups during the evaluated period.

All groups showed a significant decrease in the

Table 2. Mean forces ( $\mathrm{g}$ and $\%$ ) measured at each time interval.

\begin{tabular}{cccccccc}
\hline \multirow{2}{*}{ Chain } & Force & $\begin{array}{c}\text { Initial } \\
\text { Mean (SD) }\end{array}$ & $\begin{array}{c}1 \mathrm{~h} \\
\text { Mean (SD) }\end{array}$ & $\begin{array}{c}24 \mathrm{~h} \\
\text { Mean (SD) }\end{array}$ & $\begin{array}{c}1 \text { week } \\
\text { Mean (SD) }\end{array}$ & $\begin{array}{c}2 \text { weeks } \\
\text { Mean (SD) }\end{array}$ & $\begin{array}{c}3 \text { weeks } \\
\text { Mean (SD) }\end{array}$ \\
\hline \multirow{2}{*}{$\mathrm{PC}$} & $\mathrm{g}$ & $171.5(8.7) \mathrm{a}$ & $131.5(11.0) \mathrm{b}$ & $109.0(17.8) \mathrm{c}$ & $102.2(18.1) \mathrm{c}$ & $99.54(17.7) \mathrm{c}$ & $96.9(16.8) \mathrm{c}$ \\
& $\%$ & $100 \mathrm{~A}$ & $76.8 \mathrm{~A}$ & $63.7 \mathrm{~A}$ & $59.9 \mathrm{~A}$ & $58.35 \mathrm{~A}$ & $56.8 \mathrm{~A}$ \\
$\mathrm{MC}$ & $\mathrm{g}$ & $193.9(10.2) \mathrm{a}$ & $167.2(15.0) \mathrm{b}$ & $151.2(12.6) \mathrm{bc}$ & $140.7(15.4) \mathrm{cd}$ & $136.69(12.9) \mathrm{cd}$ & $128.8(13.2) \mathrm{d}$ \\
& $\%$ & $100 \mathrm{~B}$ & $86.3 \mathrm{~B}$ & $78.2 \mathrm{~B}$ & $72.7 \mathrm{~B}$ & $70.65 \mathrm{~B}$ & $66.6 \mathrm{AB}$ \\
$\mathrm{SSC}$ & $\mathrm{g}$ & $176.8(10.3) \mathrm{a}$ & $151.1(10.3) \mathrm{b}$ & $139.3(10.9) \mathrm{bc}$ & $134.0(17.4) \mathrm{c}$ & $127.46(16.5) \mathrm{c}$ & $124.8(15.9) \mathrm{c}$ \\
& $\%$ & $100 \mathrm{~A}$ & $85.7 \mathrm{~B}$ & $78.9 \mathrm{~B}$ & $75.7 \mathrm{~B}$ & $72.05 \mathrm{~B}$ & $70.7 \mathrm{~B}$ \\
\hline
\end{tabular}

PC: Plastic chain. MC: Memory chain. SSC: Super slick chain. Same lowercase letter (a, b, c, d) in the same row represents similarity ( $>0.05$; Tukey's post-hoc test) among the mean force at the different time periods in each group. The $\%$ force was used for comparison. Same uppercase letter (A, B, C, D) in the same column represents similarity ( $\mathrm{p}>0.05$; Tukey's post-hoc test) among the mean force among the groups at each time period. In the initial period, the force in grams was used for comparison and at the other periods the force in percent value was used. 
force measured after $1 \mathrm{~h}$. The decrease continued to be significant at the 24-h period for the PC group. After $24 \mathrm{~h}$, force decrease was not statistically significant for all groups. MC and SSC groups had a similar behavior at all time intervals. The tensile force for the PC group was the lowest at all time intervals.

\section{DISCUSSION}

The results of this study showed that different elastomeric chains might present different behaviors of force decrease during a period of 3 weeks. The obtained results are in accordance with previous reports showing that the greatest loss of force in elastomeric chains occurs in the first hour, although the magnitude of the loss may differ. The force decrease in the first hour ranged around $14-23 \%$ from the original force (around 180 $\mathrm{g}$ ), depending on the chain tested. Bousquet et al. (9) observed force decay of $31-40 \%$ during in vivo evaluation and using initial force of $200 \mathrm{~g}$. In a laboratory study, Kim et al. (17) used initial force around $350 \mathrm{~g}$ and found a decrease of $28-33 \%$. Lu et al. (11) tested different initial forces (370 g, $302 \mathrm{~g}$ and $240 \mathrm{~g}$ ) and observed a force decrease of $27 \%, 24 \%$ and $13 \%$, respectively. Different findings in the studies could be attributed to several methodological differences, such as elastomeric chain type tested, environment conditions, and methods of tensile testing.

The concept of optimal force is based on the hypothesis that a force of a certain magnitude and temporal characteristics would be capable of producing maximum rate of tooth movement without tissue damage and with minimum patient discomfort. There is no scientific evidence for the optimum force magnitude for orthodontic tooth movement (22). Previous studies have recommended forces between 100 and $300 \mathrm{~g}$ for retracting the canine $(21,23,24)$. A mean force of $180 \mathrm{~g}$ was considered in the present study, as it is expected to avoid hyalinization and root resorption, so the remaining force should be enough to stimulate periodontal bone resorption leading to tooth movement.

The time factor had greater impact (51.75\%) on the total force variation observed in the groups than the material factor $(12.14 \%)$. However, the types of elastomeric chains tested influenced significantly the force decrease behavior. Memory Chain and Super Slick chain maintained significantly higher levels of force than the plastic chain during all time intervals along the tested period. One hour after the initial stretch, around
$23 \%$ of the original force decayed in the PC group, while in the MC and SSC groups only $14 \%$ of the force was dissipated. At the end of the 3-week period, the original forces remaining were $57 \%, 67 \%$ and $71 \%$ for PC, MC and SSC groups, respectively.

Baty et al. (15) demonstrated that force delivery behavior of elastomeric chains varies according to the manufacturer. In the present study, chains from the same manufacturer, PC and MC, had different behaviors, while $\mathrm{MC}$ and $\mathrm{SSC}$, which are from different manufacturers, American Orthodontics and TP Orthodontics respectively, had similar behaviors during the 3 weeks of evaluation. This finding could be attributed to the different types of elastomeric chains. PC is considered a conventional ligature, otherwise $\mathrm{MC}$ and SSC are enhanced chains. These kinds of elastomeric chains with different properties were introduced later in an attempt to reduce force decrease. Manufacturers claim for the existence of continuous elastic memory (in MC) and decreased friction (in SSC), which could improve the behavior of these elastomeric chains. Both types of chains, MC and SSC, had the remaining force after 3 weeks considered clinically adequate (about $125 \mathrm{~g}$ ) for canine retraction, while, in the $\mathrm{PC}$ group, the remaining force was lower than $100 \mathrm{~g}$.

Despite the advantages of an in situ study, not all the variables could be controlled. Further in situ studies should evaluate the influence of the number of rings and the size of the elastomeric chains, as well as the permanent elongation on the force degradation.

In conclusion, in situ stretching of elastomeric chain induced force decrease during the 3-week study period after an initial $180 \mathrm{~g}$ activation. In general, the greatest force decrease occurred within the first hour. The remaining force and its percentage at each interval in enhanced chains, Memory Chain and Super Slick Chain, were greater than in the conventional one, plastic chain. After 3 weeks, only the enhanced chains maintained the force over $100 \mathrm{~g}$.

\section{RESUMO}

A hipótese testada foi que a exposição dos elásticos em cadeia ao meio bucal altera sua força de tensão. Portanto, o objetivo deste estudo foi avaliar o comportamento, in situ, de diferentes cadeias elastoméricas quando tensionadas durante 3 semanas. Três tipos de elásticos em cadeia Plastic Chain (PC), Memory Chain (MC) e Super Slick Chain (SSC) foram inseridos aleatoriamente em 3 dos quadrantes de 13 pacientes com distância fixa de $16 \mathrm{~mm}$ e força inicial de 180 g. Foi realizado ensaio de tração em uma máquina de ensaio universal EMIC nos seguintes intervalos: inicial, $1 \mathrm{~h}$, 
24 h, 1 semana, 2 semanas e 3 semanas. O teste ANOVA a dois critérios foi aplicado para verificar a influência do material e do tempo na degradação da força. Subsequentemente, foi utilizado o teste ANOVA a um critério e pós-teste de Tukey para identificar diferenças estatísticas $(p<0,05)$, intra-grupo e inter-grupo, na força remanescente ( $\mathrm{g} \mathrm{e} \%$ ). Tanto o material quanto o tempo tiveram efeito significativo na degradação da força. Todos os grupos mostraram diminuição significativa da força depois de 1 h sob tensão (23\% para o PC e $14 \%$ para o MC e SSC). Ao final do período de 3 semanas, a força remanescente foi de $57 \%$ (96 g), $67 \%$ (129g) e $71 \%$ (125 g) para o PC, MC e SSC, respectivamente. A exposição dos elásticos em cadeia ao meio bucal alterou a força de tensão. No geral, a maior diminuição da força ocorreu na primeira hora. A força remanescente testada em cada intervalo foi maior para os elásticos reforçados (MC e SSC) do que para o elástico convencional (PC). Após 3 semanas, apenas os elásticos reforçados mantiveram a força acima de $100 \mathrm{~g}$.

\section{REFERENCES}

1. Baty DL, Storie DJ, Von Fraunhofer JA. Synthetic elastomeric chains: a literature review. Am J Orthod Dentofacial Orthop 1994;105:536-542.

2. Casaccia GR, Gomes Jn C, Alviano DS, de Oliveira Ruellas AC, Sant' Anna EF. Microbiological evaluation of elastomeric chains. Angle Orthod 2007;77:890-893.

3. Eliades T, Eliades G, Silikas N, Watts DC. Tensile properties of orthodontic elastomeric chains. Eur J Orthod 2004;26:157-162.

4. Josell SD, Leiss JB, Rekow ED. Force degradation in elastomeric chains. Sem Orthod 1997;3:189-197.

5. Santos RL, Pithon MM, Martins FO, Romanos MTV, Ruellas ACO. Cytotoxicity of latex and non-latex orthodontic elastomeric ligatures on L929 mouse fibroblasts. Braz Dent J 2010;21:205210.

6. Suri S, Utreja A. Management of a hyperdivergent class III malocclusion, maxillary midline diastema, and infected mandibular incisors in a young adult. Am J Orthod Dentofacial Orthop 2003; 124:725-734.

7. Mezomo M, de Lima ES, de Menezes LM, Weissheimer A, Allgayer S. Maxillary canine retraction with self-ligating and conventional brackets. Angle Orthod 2011;81:292-297.

8. Nightingale C, Jones SP. A clinical investigation of force devivery system for orthodontic space closure. J Orthod 2003;30:229-236.

9. Bousquet JAJ, Tuesta O, Flores-Mir C. In vivo comparison of force decay between injection molded and die-cut stamped elastomers.
Am J Orthod Dentofacial Orthop 2006;129:384-389.

10. Kersey ML, Glover KE, Heo G, Raboud D, Major PW. A comparison of dynamic and static testing of latex and nonlatex orthodontic elastics. Angle Orthod 2003;73:181-186.

11. Lu TC, Wang WN, Tarng TH, Chen JW. Force decay of elastomeric chain - a serial study. Part II. Am J Orthod Dentofacial Orthop 1993;104:373-377.

12. Rock WP, Orth D, Wilson HJ, Tech MS, Chem C, Fisher SE. A laboratory investigation of orthodontic elastomeric chains. Br J Orthod 1985;12:202-207.

13. Crawford NL, McCarthy C, Murphy TC, Benson PE. Physical properties of conventional and Super Slick elastomeric ligatures after intraoral use. Angle Orthod 2009;80:175-181.

14. Magno AFF, Enoki C, Ito IY, Matsumoto MAN, Faria G, NelsonFilho P. In-vivo evaluation of the contamination of Super Slick elastomeric rings by Streptococcus mutans in orthodontic patients. Am J Orthod Dentofacial Orthop 2008;133:S104-S109.

15. Baty DL, Volz JE, von Fraunhofer JA. Force delivery properties of colored elastomeric modules. Am J Orthod Dentofacial Orthop 1994;106:40-46.

16. Nattrass C, Ireland AJ, Sherriff M. The effect of environmental factors on elastomeric chain and nickel titanium coil springs. Eur J Orthod 1998;20:169-176.

17. Kim K-H, Chung C-H, Choy K, Lee J-S, Vanarsdall RL. Effects of prestretching on force degradation of synthetic elastomeric chains. Am J Orthod Dentofacial Orthop 2005;128:477-482.

18. Kuster R, Ingervall B, Burgin W. Laboratory and intra oral tests of the degradation of elastic chains. Eur J Orthod 1986;8:202-208.

19. Balhoff DA, Schuldberg M, Hagan JL, Ballard RW, Armbruster PC. Force decay of elastomeric chains - a mechanical design and product comparison study. J Orthod 2011;38:40-47.

20. Andreasen GF, Bishara S. Comparison of Alastik Chains with elastics involved with intra-arch molar to molar forces. Angle Orthod 1970;40:151-158.

21. Storey E, Smith R. Force in Orthodontics and its relation to tooth movement. Aust J Orthod 1952;56:11-18.

22. Ren Y, Maltha JC, Kuijpers-Jagtman AM. Optimum force magnitude for orthodontic tooth movement: a systematic literature review. Angle Orthod 2003;73:86-92.

23. Boester $\mathrm{CH}$, Johnston LE. A clinical investigation of the concepts of differential and optimal force in canine retraction. Angle Orthod 1974;44:113-119.

24. Hixon E, Atikan H, Callow G, McDonald H, Tacy R. Optimal force, differential force and anchorage. Am J Orthod 1969;55:437457. 